\title{
World Journal of Child retroperitoneal malignant
Pediatric Surgery teratoma at the Mother and Child University Hospital Lagune of Cotonou: about a case
}

Antoine Séraphin Gbenou, ${ }^{1}$ Jerome Bonou, ${ }^{1}$ Michel Armand Fiogbe, ${ }^{2}$ Rouma Sani Bankole ${ }^{3}$

To cite: Gbenou AS, Bonou J, Fiogbe MA, et al. Child retroperitoneal malignant teratoma at the Mother and Child University Hospital Lagune of Cotonou: about a case. World JnI Ped Surgery 2020;3:e000102. doi:10.1136/wjps-2019-000102

Accepted 12 March 2020

\section{Check for updates}

(C) Author(s) (or their employer(s)) 2020. Re-use permitted under CC BY-NC. No commercial re-use. See rights and permissions. Published by BMJ.

${ }^{1}$ Pediatric Surgery, University Hospital of Mother and Child Lagune, Cotonou, Benin ${ }^{2}$ Pediatric Surgery, National University Hospital HKM, Cotonou, Benin

${ }^{3}$ Pediatric Surgery, University Hospital Treichville, Abidjan, Côte d'Ivoire

Correspondence to Dr Antoine Séraphin Gbenou; seraphin_gbenou@yahoo.fr

\section{INTRODUCTION}

Retroperitoneal malignant teratoma is a rare congenital tumor, representing 1\%-10\% of retroperitoneal tumors in children. ${ }^{12} \mathrm{~A}$ pathological migration of primitive germ cells to the genital ridges can stop at various levels, which explains the localizations of these tumors. ${ }^{3}$ The diagnosis is done either prenatally, or later in front of an abdominal mass. ${ }^{45}$ We reported a case treated in our department and reviewed the diagnostic and therapeutic aspects of its management.

\section{OBSERVATION}

It was a 3-year-old child, weighing $12 \mathrm{~kg}$, without any particular history, examined during a foreign Non-Governmental Organisation (NGO) surgical mission. The child had an abdominal mass that gradually increased in volume over a period of 2 years. The general condition was moderately impaired.

Physical examination, found a swollen abdomen with collateral venous circulation, a voluminous mass occupying almost the entire abdominal cavity except the hypogastrium, the left side and iliac fossa, without digestive or urinary disorders. Abdominal ultrasonography (figure 1) and abdominal CT (figure 2) revealed a mixed, heterogeneous right retroperitoneal tumor containing cystic areas and calcifications with a normal kidney. The alpha-fetoprotein level was up to $301 \mathrm{ng} / \mathrm{mL}$.

Surgical treatment consisted of a complete tumor resection (figure 3) with some cystic pouches puncture.

Macroscopic examination of the specimen weighing $4 \mathrm{~kg}$, revealed a mixed tumor with solid tissue and cysts, and its standard X-ray (figure 4) confirmed the presence of bone tissue. Immediate postoperative follow-up was simple and the child was discharged. The histology concluded to retroperitoneal teratoma with a contingent of malignant vitelline cells.

The parents refused a new hospitalization and the proposed free chemotherapy. Three months after surgery she presented a poor general condition with parietal and peritoneal nodules that evoked peritoneal carcinomatosis. With the persistent refusal of chemotherapy by the parents, the child was lost of sight and died two months later.

\section{DISCUSSION}

\section{Diagnostic aspects}

The discovery of a retroperitoneal malignant teratoma is often fortuitous. ${ }^{1}$ It is either discovered prenatally by obstetrical ultrasound, ${ }^{26}$ or at an advanced age ${ }^{45}$ with a first pic before three years among female. ${ }^{78}$ The latter is consistent with our observation.

Clinically, asymptomatic in 15\%-30\% of cases, it is most often seen as an abdominal mass that often lays on the right. ${ }^{18}$ The general status may change with a significant loss of weight ${ }^{19}$ with signs of compression of neighbouring organs resulting in collateral venous circulation. ${ }^{18}$

The dosage of alphafoetoprotein (AFP) and the gonadotropin hormone chorionic markers ${ }^{11011}$ are crucial for therapy and monitoring. ${ }^{12} 13$ The high AFP level in our patient confirmed the malignancy of the tumor.

Standard X-rays may reveal calcifications, suggesting the presence of teeth or bone. ${ }^{614}$ This exam of the operative specimen, showed calcifications and bone structures.

The ultrasound analyzes various components of the tumor mass, as cystic zones or shadow cone related to the hair, teeth or calcifications. ${ }^{6}{ }^{14}$ In this case, ultrasonography only a revealed a heterogeneous mixed mass, 


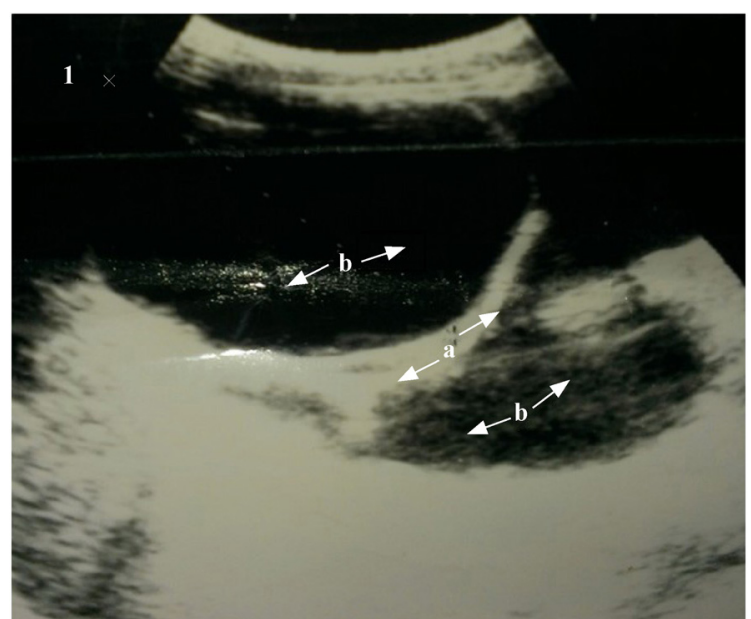

Figure 1 Ultrasound image showing a solid component mass (a) and fluid (b).

with solid tissue and fluid components. The CT scan performed confirmed the heterogeneous and mixed appearance of the tumor mass and showed a normal right kidney.

Magnetic resonance imaging (MRI), which is not performed, reveal more details of the mass, and can highlight its pedicle. ${ }^{16}$

Histological examination specifies the anatomopathological type and provides the therapeutic approach. ${ }^{17}$ It indicated a retroperitoneal teratoma with a malignant contingent of vitelline cells in this case.

\section{Therapeutic aspects}

In the treatment of a mixed tumor with a malignant contingent, neo and/or adjuvant chemotherapy is required. ${ }^{13} 15$ The purpose of adjuvant chemotherapy is to destroy the tumor cells seeded in the peritoneal cavity during surgery. This would be indicated for

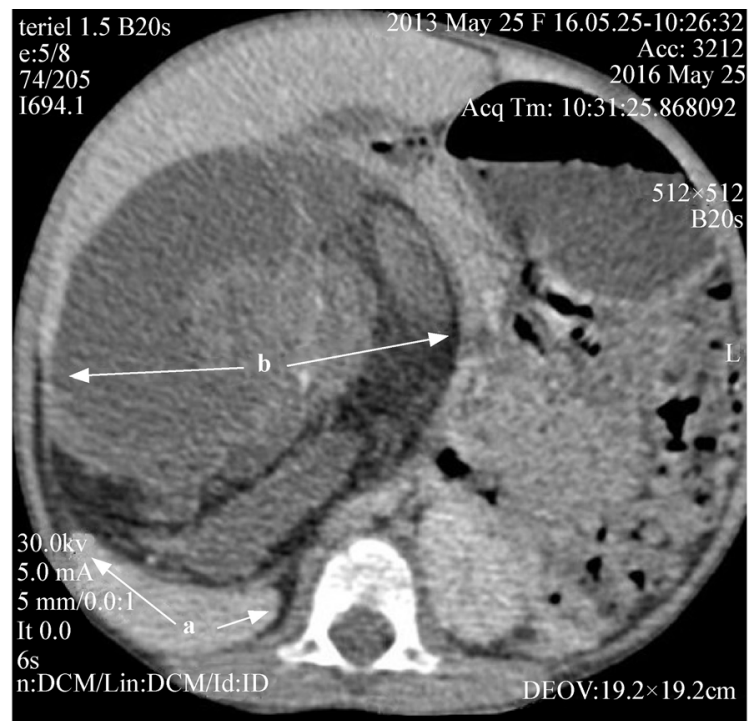

Figure 2 CT image showing, a normal right kidney (a), well separated from a mixed heterogeneous right retroperitoneal mass (b) with presence of calcifications.

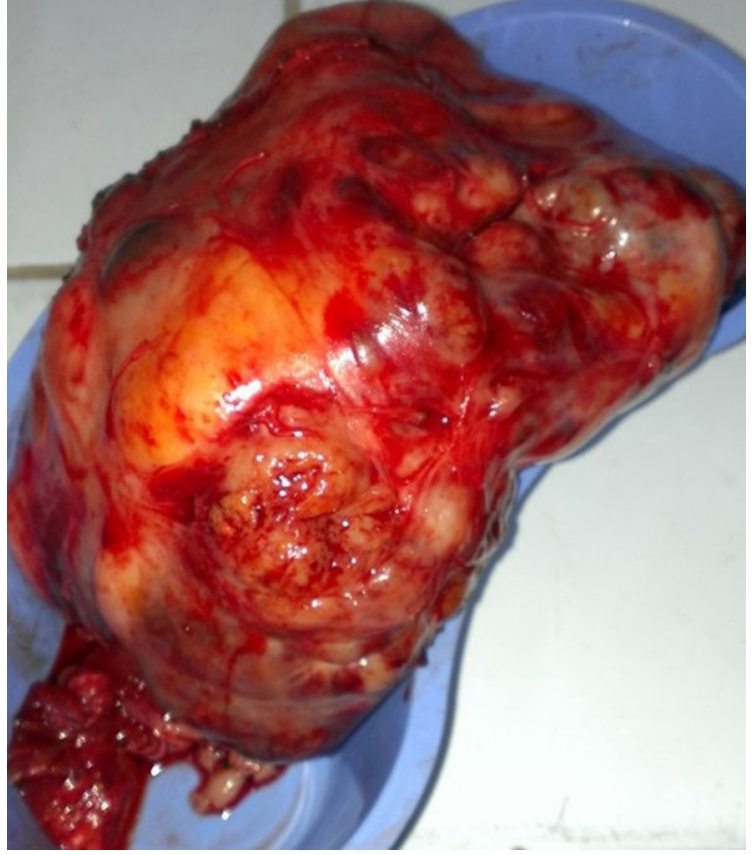

Figure 3 Solid portion of teratoma in a cup after opening and aspiration of cysts.

puncture-aspiration manipulations of cystic pouches performed intraoperatively.

In this case, there were no complications during tumor removal, contrary to Rattan and $a{ }^{13},{ }^{13}$ who reported an inferior vena cava intraoperative lesion that was repaired immediately.

The evolution is generally good when the treatment is well conducted and well monitored.$^{15}$ However, the proposed chemotherapy following the histological results was refused by the parents. A tumor relapse was observed with appearance of peritoneal and parietal nodules. The

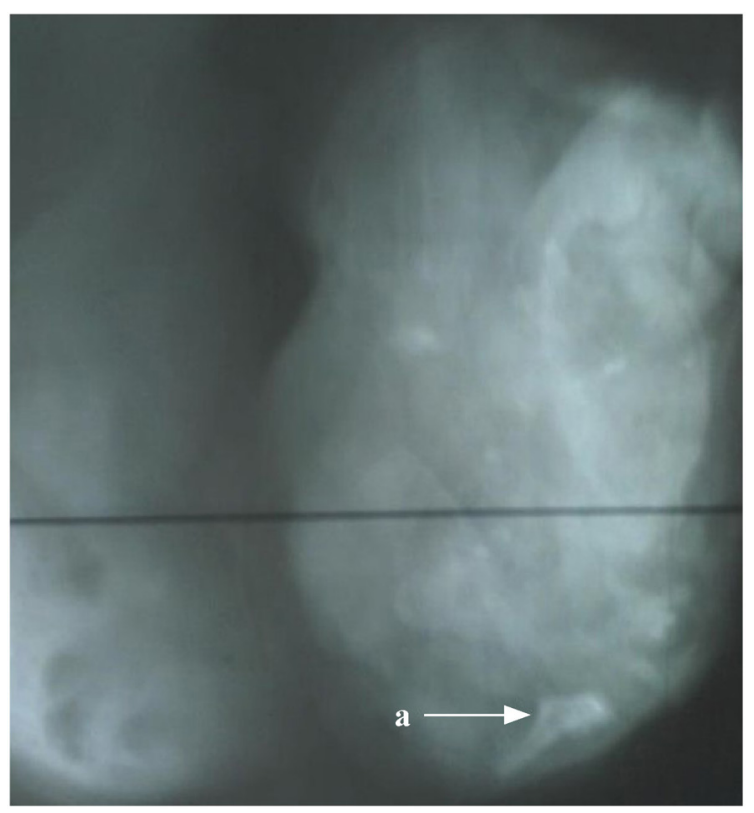

Figure 4 X-ray of teratoma after excision and opening with bone structures (a). 
child lost sight before dying two months later. Mouad et $\mathrm{al}^{16}$ reported a case of death as well.

Various sociological factors can be evoked during care, including late access to care due to poverty. The refusal of free chemotherapy could be associated with the manifestations of religious beliefs and ignorance. These factors were obstacles to the malignant tumor management protocol.

\section{CONCLUSION}

Retroperitoneal malignant teratomas are rare tumors in children. In our case the diagnosis was late. Multidisciplinary treatment was handicapped by socio-economic factors. Early diagnosis associated with preoperative and postoperative chemotherapy is of great meaning for a good prognosis.

Acknowledgements We present our sincerest acknowledgments to the French NGO 'la Chaine de l'Espoir' for partnership and humanitarian missions.

Contributors ASG and JB contributed to manuscript preparation ; ASG, MAF and RSB contributed to manuscript editing and review.

Funding The authors have not declared a specific grant for this research from any funding agency in the public, commercial or not-for-profit sectors.

Competing interests None declared.

Patient consent for publication Writtern consent for publication of the details including images of the patient has been obtained from the parents.

Ethics approval This study has been approved by the hospital ethics committee.

Provenance and peer review Not commissioned; externally peer reviewed.

Data availability statement All data relevant to the study are included in the article or uploaded as supplementary information.

Open access This is an open access article distributed in accordance with the Creative Commons Attribution Non Commercial (CC BY-NC 4.0) license, which permits others to distribute, remix, adapt, build upon this work non-commercially, and license their derivative works on different terms, provided the original work is properly cited, appropriate credit is given, any changes made indicated, and the use is non-commercial. See: http://creativecommons.org/licenses/by-nc/4.0/.

\section{REFERENCES}

1 El Azzouzi D, Lasseri A. The peritoneal teratoma of the child: about a case and review of the literature. Moroccan Journal of Medical Sciences 2013;18:1-5.

2 Asai S, Ishimoto $\mathrm{H}, \mathrm{Kim} \mathrm{SH}$, et al. Prenatal diagnosis of retroperitoneal teratoma: a case report and review of the literature. Fetal Diagn Ther 2009;25:76-8.

3 De Backer A, Madern GC, Hazebroek FWJ. Retroperitoneal germ cell tumors: a clinical study of 12 patients. J Pediatr Surg 2005;40:1475-81.

4 Chaudhary A, Misra S, Wakhlu A, et al. Retroperitoneal teratomas in children. Indian J Pediatr 2006;73:221-3.

5 Sadaqat AK, Tariq M, Zeeshan SM, et al. Retroperitoneal teratoma in an adult presenting with painful abdominal mass: case history and literature review. BJMP 2012;5:43-5.

6 Claudon M, Regent D, Stines J, et al. Diagnosis of retroperitoneal tumors: place of imaging. Radiology Journal 2004;85:1424.

7 Mathur P, Lopez-Viego MA, Howell M. Giant Primary Retroperitoneal Teratoma in an Adult: A Case Report. Case Reports in Medicine Volume 2010, Article ID 650424, 3 pages.

8 Sandhya V, Shanthakumari S. Retroperitoneal fetiformteratoma. Indian J Pathol Micr 2010;53:581.

9 Nguyen CT, Kratovil T, Edwards MJ. Retroperitoneal teratoma presenting as an abscess in childhood. J Pediatr Surg 2007;42:e21-3.

10 Sarin YK, Yogesh KS. Peritonitis caused by rupture of infected retroperitoneal teratoma. APSP J Case Rep 2012;3:2.

11 Eyssartier E, Harper L, Michel J-L, et al. Rapidly growing mature retroperitoneal teratomas. J Pediatr Hematol Oncol 2009;31:705-6.

12 Sinha S, Sarin YK, Khurana N. Prenatally diagnosed retroperitoneal fetus-in-fetu with ipsilateral testicular atrophy: a case report. $J$ Neonatal Surg 2012;1:41.

13 Rattan KN, Kadian YS, Nair VJ, et al. Primary retroperitoneal teratomas in children: a single institution experience. Afr J Paediatr Surg 2010;7:5-8.

14 Alison M, Eiss D, Helenon O. Diagnostic d'une masse rétropéritonéale. Feuillets de Radiologie 2005;45:225-7.

15 French Society of pediatric oncology; Extra-cerebral germ tumors. treatment pathways TGM95 1994

16 Mouad S, Abdellatif K. Teratome mature géant retroperitoneal. Pan African Medical Journal 2014;18:147. 